\title{
Inclusion of different exogenous fibrolytic enzymes to dry jowar fodder and their effect on in vitro total gas production
}

\author{
S.H. Sipai, K.S. Dutta, H.H. Savsani, K.S. Murthy, P.H. Vataliya, J.A. Chavda and A.P. Gajera \\ Department of Animal Nutrition, \\ College of Veterinary Science and Animal Husbandry, Junagadh Agricultural University, Junagadh, Gujarat, India \\ Corresponding author: S.H. Sipai, email: sarfaraz4489@gmail.com \\ Received: 04-07-2013, Revised: 13-08-2013, Accepted: 14-08-2013, Published online: 22-09-2013
}

doi: 10.14202/vetworld.2013.839-843 How to cite this article: Sipai SH, Dutta KS, Savsani HH, Murthy KS, Vataliya PH, Chavda J A and Gajera AP (2013) Inclusion of different exogenous fibrolytic enzymes to dry jowar fodder and their effect on in vitro total gas production, Veterinary World 6(11): 839-843.

\begin{abstract}
Aim: Our objective was to estimate in-vitro gas production from dry jowar fodder added with different concentrations of exogenous fibrolytic enzymes (EFEs) like neutral cellulase and fungal xylanase.

Materials and Methods: 34 different samples of dry jowar fodder were prepared according to different concentrations of neutral cellulase, fungal xylanase and neutral cellulase + fungal xylanase (1:1). Sample not containing any enzymes was considered as the control group. These 34 samples were subjected to further in vitro gas production analysis.

Results: Statistically, significantly higher $(\mathrm{P} \leq 0.05)$ potential gas production was recorded for $0.7 \%$ at $6 \mathrm{hr}$ period, $0.7 \%$ at $12 \mathrm{hr}$ period, $0.7 \%, 0.8 \%$ at $18 \mathrm{hr}$ period and $0.7 \%, 0.8 \%$ at $24 \mathrm{hr}$ period in the samples treated with neutral cellulase. Significantly higher potential gas production was recorded for $0.5 \%, 0.8 \%$ at $6 \mathrm{hr}$ period, $0.5 \%$, $0.6 \%, 0.8 \%$ at $12 \mathrm{hr}$ period, $0.8 \%$ at $18 \mathrm{hr}$ period and $0.5 \%, 0.6 \%, 0.8 \%$ at $24 \mathrm{hr}$ period in the samples treated with fungal xylanase. Significantly higher potential gas production was recorded for $0.6 \%, 0.6 \%, 0.8 \%$ at $6 \mathrm{hr}$ period, $0.6 \%, 0.8 \%$ at $12 \mathrm{hr}$ period, $0.6 \%, 0.8 \%$ at $18 \mathrm{hr}$ period and $0.6 \%, 0.8 \%$ at $24 \mathrm{hr}$ period in the samples treated with mixture of neutral cellulase + fungal xylanase $(1: 1)$.
\end{abstract}

Conclusion: Addition of neutral cellulase and fungal xylanase into the samples of dry jowar fodder increased in vitro total potential gas production. EFEs increase substrate degradation and there by improve the nutritive value of dry jowar fodder.

Keywords: dry jowar fodder, fungal xylanase, neutral cellulase, total gas production

\section{Introduction}

Over the years various forage breeding programs have been used to achieve improved forage quality. Despite significant genetic improvements, there is excessive loss of nutrients by ruminants due to limitations in forage degradability. To improve the forage degradability various physical, chemical and biological treatments are routinely used. The use of exogenous fibrolytic enzymes (EFEs) to improve forage degradability holds promise as a means of improving the productive efficiency of ruminants. Action of EFEs on feedstuffs can release more nutrients, because EFE can break down specific chemical bonds in the feedstuffs that are not usually degraded by endogenous enzymes [1]. EFEs increase digestion of dry matter and fiber as measured in situ [2], in vitro [3,4] and in sacco [5]. Previously EFEs are only used to improve the nutritive value of feeds for non ruminants particularly in broiler diets. In ruminant feeds EFEs were not used because of the perception

Copyright: The authors. This article is an open access article licensed under the terms of the Creative Commons Attribution License (http://creativecommons.org/licenses/by/2.0) which permits unrestricted use, distribution and reproduction in any medium, provided the work is properly cited. that exogenous enzymes are not effective in the rumen and also that they do not increase the hydrolytic capacity of the rumen. These concerns have been disproved by several recent studies which showed that supplementation of EFEs to ruminant feeds increase their nutritive value and consequently improve the animal's productivity $[6,7]$.

Addition of EFEs increases microbial growth and increases the production of microbial proteins [8]. Addition of fibrolytic enzymes to feedstuffs increased dry matter $(\mathrm{DM})$, crude protein $(\mathrm{CP})$, and soluble fractions of diets, -an affect that provides energy and also leads to rapid microbial growth [9]. Increased number of ruminal bacteria could then lead to increased microbial colonization of the feed particles which can result in increased total gas production. Jowar fodder is commonly used by farmers of Saurashtra region in Gujarat. Hence this research was performed to evaluate the effect of different EFEs on the in vitro digestibility of dry jowar fodder.

\section{Materials and Methods}

Ethical approval: The study was approved by the committee formed for the research by the university authorities and was conducted at Cattle Breeding Farm, 
Table-1. Effect of neutral cellulase on in vitro gas production $(\mathrm{ml})$ from dry jowar

\begin{tabular}{lllll}
\hline Level of enzyme (\%) & \multicolumn{4}{c}{ Gas production (ml) at different periods } \\
\cline { 2 - 5 } & $\mathbf{6} \mathbf{~ h r}$ & $\mathbf{1 2} \mathbf{~ h r}$ & $\mathbf{1 8} \mathbf{~ h r}$ & $\mathbf{2 4} \mathbf{~ h r}$ \\
\hline Control & $25.33^{\mathrm{d}} \pm 1.47$ & $47.67^{\mathrm{a}} \pm 0.82$ & $65.00^{\mathrm{c}} \pm 1.87$ & $77.67^{\mathrm{d}} \pm 1.08$ \\
0.01 & $25.67^{\mathrm{d}} \pm 0.41$ & $48.33^{\mathrm{de}} \pm 1.47$ & $66.33^{\mathrm{c}} \pm 1.08$ & $80.33^{\mathrm{d}} \pm 1.63$ \\
0.1 & $28.33^{\mathrm{c}} \pm 1.08$ & $52.33^{\mathrm{c}} \pm 1.78$ & $72.67^{\mathrm{b}} \pm 2.16$ & $86.33^{\mathrm{c}} \pm 1.08$ \\
0.2 & $33.67^{\mathrm{b}} \pm 0.82$ & $51.67^{\mathrm{cd}} \pm 1.08$ & $73.00^{\mathrm{b}} \pm 1.87$ & $87.33^{\mathrm{bc}} \pm 2.48$ \\
0.3 & $33.67^{\mathrm{b}} \pm 1.78$ & $54.67^{\mathrm{abc}} \pm 1.47$ & $723^{\mathrm{b}} \pm 1.08$ & $89.67^{\mathrm{abc}} \pm 1.78$ \\
0.4 & $33.33^{\mathrm{b}} \pm 1.08$ & $53.67^{\mathrm{bc}} \pm 1.78$ & $73.67^{\mathrm{b}} \pm 1.78$ & $87.33^{\mathrm{bc}} \pm 1.08$ \\
0.5 & $323^{\mathrm{ab}} \pm 1.47$ & $523^{\mathrm{abc}} \pm 2.48$ & $73.33^{\mathrm{b}} \pm 1.08$ & $87.67^{\mathrm{bc}} \pm 1.47$ \\
0.6 & $33.33^{\mathrm{b}} \pm 0.82$ & $53.67^{\mathrm{bc}} \pm 1.47$ & $74.00^{\mathrm{b}} \pm 2.55$ & $88.67^{\mathrm{bc}} \pm 1.47$ \\
0.7 & $36.67^{\mathrm{a}} \pm 0.82$ & $58.33^{\mathrm{a}} \pm 1.08$ & $78.67^{\mathrm{a}} \pm 1.08$ & $92.67^{\mathrm{a}} \pm 1.08$ \\
0.8 & $36.00^{\mathrm{abb}} \pm 0.71$ & $57.00^{2 \mathrm{ab}} \pm 2.12$ & $78.33^{\mathrm{a}} \pm 0.41$ & $93.33^{\mathrm{a}} \pm 0.82$ \\
0.9 & $35.67^{\mathrm{ab}} \pm 0.41$ & $56.67^{\mathrm{ab}} \pm 0.82$ & $76.00^{\mathrm{ab}} \pm 0.71$ & $90.00^{\mathrm{abc}} \pm 0.71$ \\
1 & $35.67^{\mathrm{ab}} \pm 0.41$ & $55.33^{\mathrm{abc}} \pm 1.78$ & $75.33^{\mathrm{ab}} \pm 1.78$ & $90.33^{\mathrm{ab}} \pm 2.16$ \\
SEM & 0.84 & 1.30 & 1.29 & 1.22 \\
CD at 5\% & 2.47 & 3.79 & 3.76 & 3.56 \\
\hline
\end{tabular}

* Means in a column with different superscripts indicate significant $(P \leq 0.05)$ difference.

Junagadh Agricultural University, Junagadh. The exogenous fibrolytic enzymes i.e. neutral cellulase and fungal xylanase used in this study were directly purchased from Aumgene Biosciences Pvt. Ltd., Surat, Gujarat. The activities of the enzymes were 2,00,000 units/gm and 3,000 units/gm for fungal xylanase and neutral cellulase, respectively.

Sample preparation: Sample of dry jowar fodder was collected from cattle breeding farm, Junagadh. Fully matured sample of jowar fodder was used for this research. Jowar fodder was harvested by labor after 2.5 month of maturity period. No machines were used for harvesting the Jowar fodder. Sample was dried in hot air oven at $70^{\circ} \mathrm{C}$ for overnight. Sample was ground to reduce particle size $(0.5 \mathrm{~mm})$ and stored in polythene bag at room temperature $\left(37^{\circ} \mathrm{C}\right)$ nalysis. Eleven different samples of dry jowar fodder were prepared according to different levels of neutral cellulase i.e. $0.01,0.1,0.2$, $0.3,0.4,0.5,0.6,0.7,0.8,0.9$ and $1 \%$. Eleven different samples of dry jowar fodder were prepared according to different levels of fungal xylanase i.e. $0.01,0.1,0.2$, $0.3,0.4,0.5,0.6,0.7,0.8,0.9$ and $1 \%$. Eleven different samples of dry jowar fodder were prepared according to different levels of neutral cellulase + fungal xylanase (1:1) i.e. 0.01, 0.1, 0.2, 0.3, 0.4, 0.5, 0.6, 0.7, $0.8,0.9$ and $1 \%$. Sample of dry jowar fodder not containing any of the enzymes was considered as control. These 34 samples of dry jowar fodder were subjected to in vitro analysis.

Estimation of total gas production: Modified method was used for estimation of total gas production $[10,11]$. In this method increasing the amount of sample from 200 to $500 \mathrm{mg}$ and increasing the amount of buffer twofold as a result the incubation volume increase from 30 $\mathrm{ml}$ in the method [12] to $40 \mathrm{ml}$ in the modified method. $500 \mathrm{mg}$ sample quantity was chosen to decrease analytical error but at the same time our goal was to avoid production of more than $90 \mathrm{ml}$ gas [13].

Experimental substrate $(500 \mathrm{mg}$ ) was weighed on a plastic boat with removable stem and placed into the bottom of the glass syringe without sticking to the sides of the syringes. The piston was lubricated with petroleum jelly and pushed inside the syringe. Three syringes with only buffered rumen fluid are incubated and considered as the blank. All the syringes were incubated at $39 \pm 0.5^{\circ} \mathrm{C}$ for $24 \mathrm{hr}$ period. In-vitro medium was prepared by mixing $300 \mathrm{ml}$ distilled water, $200 \mathrm{ml}$ rumen buffer solution and $100 \mathrm{ml}$ macro minerals solution, $0.4 \mathrm{ml}$ Resazurine solution, $0.04 \mathrm{ml}$ micro minerals solution and $22 \mathrm{ml}$ reducing solution (prepared fresh and added just prior to incubation). The medium was pre-warmed to $39^{\circ} \mathrm{C}$ and bubbled with $\mathrm{CO}_{2}$ till the blue colour of the medium disappeared. After the medium became colorless, $200 \mathrm{ml}$ of strained rumen liquor (SRL) was added. Then $40 \mathrm{ml}$ of incubation medium was injected into each syringe using pipette. Level of piston was recorded and the syringes were placed in an incubator $\left(39 \pm 0.5^{\circ} \mathrm{C}\right)$. Gas produced $(\mathrm{ml} / 500 \mathrm{mg}$ substrate) during fermentation was measured after $24 \mathrm{hrs}$.

Statistical analysis: Experimental data were analyzed as per CRD [14]. The treatment means were compared by Duncan's new multiple range test [15]. P-values less than 0.05 are considered to be statistically significant.

\section{Results and Discussion}

The gas production technique has been widely used for evaluation of nutritive value particularly for various types of tropical plants $[16,17]$ and for different classes of feeds [18]. In vitro gas production technique helps to quantify nutrient utilization in a better way by its accuracy in describing digestibility in animals [19]. This technique can be used to predict animal's performance at a much lower cost. In this study significant effects of EFE treatment on fractional gas production at four different periods i.e. $6 \mathrm{hr}, 12 \mathrm{hr}, 18 \mathrm{hr}$ and $24 \mathrm{hr}$ periods of incubation was recorded. Effect of different levels of neutral cellulase enzyme on in vitro gas production from dry jowar fodder is shown in Table-1. Our results show that gas production parameters from all treatment groups were significantly $(\mathrm{P} \leq 0.05)$ comparable with those of the control group, except for neutral cellulase enzyme level at $0.01 \%$ in dry jowar 
Table-2. Effect of fungal xylanase on in vitro gas production ( $\mathrm{ml}$ ) from dry jowar

\begin{tabular}{|c|c|c|c|c|}
\hline \multirow[t]{2}{*}{ Level of enzyme (\%) } & \multicolumn{4}{|c|}{ Gas production $(\mathrm{ml})$ at different periods } \\
\hline & $6 \mathrm{hr}$ & $12 \mathrm{hr}$ & $18 \mathrm{hr}$ & $24 \mathrm{hr}$ \\
\hline Control & $25.33^{\dagger} \pm 1.47$ & $48.33^{\mathrm{e}} \pm 1.47$ & $65.00^{f} \pm 1.87$ & $77.67^{d} \pm 1.08$ \\
\hline 0.01 & $27.00^{\text {ef }} \pm 0.71$ & $51.67^{d} \pm 0.82$ & $69.33^{\mathrm{e}} \pm 1.08$ & $81.67^{\text {cd }} \pm 1.47$ \\
\hline 0.1 & $29.33^{\text {de }} \pm 0.41$ & $52.00^{d} \pm 0.71$ & $73.33^{\text {cde }} \pm 2.48$ & $86.33^{b} \pm 2.86$ \\
\hline 0.2 & $29.00^{\text {de }} \pm 0.71$ & $54.67^{\mathrm{bcd}} \pm 1.08$ & $71.33^{\mathrm{de}} \pm 1.08$ & $86.00^{\mathrm{bc}} \pm 1.87$ \\
\hline 0.3 & $31.33^{\text {cd }} \pm 1.08$ & $53.00^{\text {cd }} \pm 0.71$ & $73.67^{\text {cde }} \pm 1.63$ & $85.33^{b c} \pm 1.08$ \\
\hline 0.4 & $29.33^{\mathrm{de}} \pm 2.16$ & $53.33^{\text {cd }} \pm 1.47$ & $75.67^{\mathrm{abcd}} \pm 2.16$ & $87.67^{\mathrm{ab}} \pm 2.68$ \\
\hline 0.5 & $36.67^{\mathrm{a}} \pm 0.82$ & $58.33^{\mathrm{a}} \pm 1.08$ & $79.33^{\mathrm{ab}} \pm 2.16$ & $92.00^{a} \pm 1.87$ \\
\hline 0.6 & $31.67^{\text {cd }} \pm 1.08$ & $58.33^{\mathrm{a}} \pm 1.08$ & $78.67^{\mathrm{ab}} \pm 2.16$ & $91.67^{a} \pm 1.63$ \\
\hline 0.7 & $35.33^{\mathrm{ab}} \pm 1.63$ & $55.33^{\mathrm{bc}} \pm 1.47$ & $75.00^{\text {bcd }} \pm 1.41$ & $89.33^{\mathrm{ab}} \pm 0.41$ \\
\hline 0.8 & $37.00^{a} \pm 0.71$ & $59.67^{\mathrm{a}} \pm 1.08$ & $79.67^{a} \pm 0.82$ & $92.33^{a} \pm 2.16$ \\
\hline 0.9 & $35.33^{\mathrm{ab}} \pm 1.08$ & $57.00^{\mathrm{ab}} \pm 1.41$ & $78.33^{\mathrm{ab}} \pm 1.78$ & $89.33^{\mathrm{ab}} \pm 1.47$ \\
\hline 1 & $33.67^{\mathrm{bc}} \pm 1.08$ & $55.33^{\mathrm{bc}} \pm 1.47$ & $76.33^{\mathrm{abc}} \pm 1.78$ & $89.67^{\mathrm{ab}} \pm 2.48$ \\
\hline SEM & 0.96 & 0.93 & 1.37 & 1.54 \\
\hline CD at $5 \%$ & 2.79 & 2.71 & 3.99 & 39 \\
\hline
\end{tabular}

* Means in a column with different superscripts indicate significant $(P \leq 0.05)$ difference.

Table-3. Effect of mixture of neutral cellulase + fungal xylanase ( $1: 1$ ) on in vitro gas production (ml) from dry jowar

\begin{tabular}{|c|c|c|c|c|}
\hline \multirow[t]{2}{*}{ Level of enzyme (\%) } & \multicolumn{4}{|c|}{ Gas production $(\mathrm{ml})$ at different periods } \\
\hline & $6 \mathrm{hr}$ & $12 \mathrm{hr}$ & $18 \mathrm{hr}$ & $24 \mathrm{hr}$ \\
\hline Control & $25.33^{d} \pm 1.47$ & $48.33^{h} \pm 1.47$ & $65.00^{\mathrm{e}} \pm 1.87$ & $77.67^{9} \pm 1.08$ \\
\hline 0.01 & $31.33^{c} \pm 0.41$ & $54.67^{g} \pm 1.08$ & $71.67^{\mathrm{d}} \pm 1.08$ & $823^{\dagger} \pm 0.82$ \\
\hline 0.1 & $31.67^{\circ} \pm 1.08$ & $57.00^{\mathrm{efg}} \pm 1.41$ & $723^{\mathrm{cd}} \pm 1.47$ & $86.00^{\text {ef }} \pm 1.41$ \\
\hline 0.2 & $31.67^{\circ} \pm 0.41$ & $57.67^{\mathrm{def}} \pm 0.41$ & $74.00^{\text {cd }} \pm 0.71$ & $86.67^{\text {ef }} \pm 0.82$ \\
\hline 0.3 & $37.67^{\mathrm{ab}} \pm 0.82$ & $61.33^{\mathrm{bc}} \pm 1.08$ & $76.33^{\mathrm{bc}} \pm 1.78$ & $92.33^{\mathrm{bc}} \pm 1.47$ \\
\hline 0.4 & $33.00^{\circ} \pm 0.71$ & $58.67^{\text {de }} \pm 0.82$ & $75.67^{\mathrm{bc}} \pm 1.08$ & $88.33^{\mathrm{de}} \pm 0.41$ \\
\hline 0.5 & $31.33^{c} \pm 1.08$ & $55.33^{\mathrm{fg}} \pm 1.47$ & $75.33^{\mathrm{c}} \pm 1.08$ & $89.67^{\text {cd }} \pm 1.47$ \\
\hline 0.6 & $38.67^{a} \pm 0.82$ & $64.67^{\mathrm{a}} \pm 1.08$ & $82.00^{\mathrm{a}} \pm 1.87$ & $96.33^{a} \pm 1.47$ \\
\hline 0.7 & $38.33^{\mathrm{a}} \pm 0.41$ & $62.67^{\mathrm{ab}} \pm 0.82$ & $80.67^{\mathrm{ab}} \pm 1.08$ & $95.67^{\mathrm{ab}} \pm 1.08$ \\
\hline 0.8 & $38.33^{\mathrm{a}} \pm 1.08$ & $623^{a} \pm 0.41$ & $81.67^{a} \pm 0.41$ & $96.00^{\mathrm{a}} \pm 1.41$ \\
\hline 0.9 & $35.67^{b} \pm 1.08$ & $59.67^{\text {bcde }} \pm 1.47$ & $77.33^{\mathrm{bc}} \pm 1.78$ & $92.00^{\mathrm{bc}} \pm 1.41$ \\
\hline 1 & $36.00^{b} \pm 0.71$ & $60.00^{\mathrm{bcd}} \pm 0.71$ & $75.33^{\mathrm{C}} \pm 1.78$ & $92.67^{\mathrm{b}} \pm 0.41$ \\
\hline SEM & 0.73 & 0.84 & 1.15 & 0.96 \\
\hline $\mathrm{CD}$ at $5 \%$ & 2.14 & 2.45 & 3.37 & 2.79 \\
\hline
\end{tabular}

* Means in a column with different superscripts indicate significant $(P \leq 0.05)$ difference.

fodder. Statistically, significantly higher $(\mathrm{P} \leq 0.05)$ potential gas production was recorded for $0.7 \%$ at $6 \mathrm{hr}$ period, $0.7 \%$ at $12 \mathrm{hr}$ period, $0.7 \%, 0.8 \%$ at $18 \mathrm{hr}$ period and $0.7 \%, 0.8 \%$ at $24 \mathrm{hr}$ period. Effect of different levels of fungal xylanase enzyme on in vitro gas production from dry jowar fodder, at four different periods is shown in Table-2. Results show that gas production parameters from all treatment groups were significantly comparable with those of control group. Data indicated that total potential gas production from samples treated with fungal xylanase is higher than the samples treated with neutral cellulase. Results indicated that up to a certain level, increasing concentrations of EFEs also increased in vitro total gas production which may be due to increased enzymatic activity at higher concentrations of EFEs.

Six enzyme products were used to examine the relationship between enzyme activities and in vitro gas production using grass and corn silage [20]. Preparations relatively high in cellulase activity increased the rate of gas production from corn silage compared with the control (no added enzyme). In contrast, products with relatively high xylanase activity did not increase gas production when glucanase activity was low [20]. Those results were similar to the effects of neutral cellulase, but contradictory to the effects of fungal xylanase in this study. This may be due to differences in the enzyme activity and samples used for in vitro analysis.

Effect of different levels of neutral cellulase + fungal xylanase (1:1) enzyme on in vitro gas production from dry jowar fodder, at four different periods is shown in Table-3. Results show that gas production parameters from all treatment groups were significantly comparable with those of control group. Significantly higher potential gas production was recorded for $0.6 \%, 0.6 \%, 0.8 \%$ at $6 \mathrm{hr}$ period, $0.6 \%$, $0.8 \%$ at $12 \mathrm{hr}$ period, $0.6 \%, 0.8 \%$ at $18 \mathrm{hr}$ period and $0.6 \%, 0.8 \%$ at $24 \mathrm{hr}$ period. Results from Table 1 to 3 indicated that highest amount of total potential gas production is recorded for samples treated with mixture of neutral cellulase + fungal xylanase (1:1) and lowest amount of total potential gas production is observed in samples treated with neutral cellulase. Our results indicate that effect of different levels of neutral cellulase + fungal xylanase (1:1) enzyme on in vitro gas production from dry jowar fodder is higher than the effects of neutral cellulase and fungal xylanase individually. Higher gas production data from the samples containing mixture of neutral cellulase + fungal xylanase (1:1) indicated that a combination of both the enzymes is beneficial rather than their individual use to improve total gas production.

The addition of neutral cellulase, fungal xylanase 
and their mixture to samples of dry jowar fodder can improve gas production fermentation. Similar results from other studies indicated that the addition of yeast and fibrolytic enzymes may improve in vitro gas production fermentation of low quality roughages [21]. In this study potential gas production rate was increased at up to a certain level of enzyme added, then the potential gas production decreased at higher level of enzymes. Ruminal cellulolytic bacteria have evolved to digest cellulose within this narrow range ( 0.05 to $0.08 \mathrm{~h}-1)$ when digesting structurally ordered, insoluble polymers of fibrous sources.

Tables 1 to 3 indicate that gas production rate is higher during early stage of incubation than during later stage of incubation. Similar result was found on effects of EFE on stimulation of ruminal fermentation during the early hours $(6 \mathrm{hr})$ of incubation but not beyond $6 \mathrm{hrs}$ [23]. The probable reason for higher gas production during early stage of incubation is that the enzyme activity during early period of incubation is higher than at later stages of incubation.

\section{Conclusion}

Addition of neutral cellulase and fungal xylanase and their mixture in a 1:1 proportion into the samples of dry jowar fodder increased total potential gas production. Thus, these results indicate that addition of EFEs increases substrate degradation and improves the nutritive value of dry jowar foder. So it is beneficial to use EFEs in animal feeding to increase the overall animal performances. Our results also indicated that in vitro gas production from dry jowar fodder increased up to a certain level of fibrolytic enzymes, then at higher level of enzymes substrate degradation decreased. We therefore conclude that medium level $(0.5 \%-0.8 \%)$ of fibrolytic enzymes is better than their lower or higher level. We also conclude that mixture of neutral cellulase + fungal xylanase (1:1) is more beneficial than just adding neutral cellulase and fungal xylanse individually to dry jowar.

\section{Authors' contributions}

SHS and JAC did the sampling and laboratory works. KSD designed and approved the study plan. HHS revised and drafted the manuscript. KSM and PHV critically reviewed the manuscript. APG did the statistical analysis. All authors read and approved the final manuscript.

\section{Acknowledgements}

We would like to thank The Dean, College of Veterinary Science \& A.H., JAU, Junagadh, for providing all funds and facilities to conduct this experiment. We would also like to thank Research Scientist, Cattle Breeding Farm for providing facilities to conduct this experiment.

\section{Competing interests}

The authors declare that they have no competing interests.

\section{References}

1. Beauchemin, K. A., Morgavi, D. P., McAllister, T. A., Yang, W. Z. and Rode, L. M. (2001) The Use of Enzymes in Ruminant Diets. In: Recent Advances in Animal Nutrition, Garnsworthy, P.C. and J. Wiseman (Eds.). Nottingham University Press, Loughborough, England, 297-322.

2. Bandla, S., Chaturvedi, O. H., Malik. R., and Asgar, M. (2010) Effect of enzyme to substrate ratio of exogenous fibrolytic and protease enzymes on in vitro gas production kinetics. The Indian Journal of Small Ruminants. 14(2):181190.

3. Yancy M. I., Valli, C. and Balakrishnan, V. (2011) Enhancing utilization of sorghum stover and groundnut haulm by pre treating them with non - starch polysaccharidase mixture. Tamilnadu Journal of Veterinary \& Animal Sciences. 7(3):150-153.

4. Vazquez, A. G., Martinez, G. M. and Rodriguez, J. P. (2011) Comparison of in vitro degradation of elephant grass and sugarcane by exogenous fibrolytic enzymes. African Journal of Microbiology Research. 5(19): 3051-3053.

5. Gallardo Ismael, Barcena Ricardo, Juan Manuel PinosRodriguez, Mario Cobos, Lorenzo Carreon and Maria Esther Ortega (2010) Influence of exogenous fibrolytic enzymes on in vitro and in sacco degradation of forages for ruminants. Italian Journal of Animal Science. 9(1):34-38.

6. Bhat, M. K. (2000) Cellulases and related enzymes in biotechnology. Biotechnol. Adv. 18: 355-383.

7. Beg, Q. K., Kapoor, M., Mahajan, L. and Hoondal, G. S. (2001) Microbial xylanases and their industrial applications: a review. Appllied Microbiology and Biotechnology. 56: 326-338.

8. Gado, H. M., Salem, A. Z., Robinson, P. H., and Hassan, M. (2009) Influence of exogenous enzymes on nutrient digestibility, extent of ruminal fermentation as well as milk production and composition in dairy cows. Animal Feed Science Technology. 154: 36-46.

9. Alvarez, G., Pinos-Rodriguez, J. M., Herrera, J. G., Garcia, J. C., Gonzalez, S. S. and Barcena, R. (2009) Effects of exogenous fibrolytic enzymes on ruminal digestibility in steers fed high fibre rations. Livestock Science. 121: 150154.

10. Makkar, H. P. S., Blümmel, M. and Becker, K. (1995) Formation of complexes between polyvinyl pyrrolidone and polyethylene glycol with tannins and their implications in gas production and true digestibility in in vitro techniques. British Journal of Nutrition. 73: 897-913.

11. Blummel, M., Makkar, H. P. S. and Becker K. (1997) In vitro gas production: a technique revisited. Journal of Animal Physiology and Animal Nutrition. 77: 24-34.

12. Menke, K. H., Raab, L., Salewski, A., Steingass, H., Fritz, D. and Schneider, W. (1979) The estimation of the digestibility and metabolizable energy content of ruminant feedstuffs from the gas production when they are incubated with rumen liquor in vitro. Journal of Agriculture Science. (Camb.). 92: 217-222.

13. Steingass, H. (1983) Bestimmung des energetischen Futterwertes von wirtschaftseigenen Futtermitteln aus der Gasbildung bei der Pansenfermentation in vitro. PhD Thesis, University of Hohenheim, Hohenheim, Germany.

14. Snedecor, G. W. and Cochran, W. G. (1994) Statistical Methods. 6th Edn., IOWA State University Press, USA. pp258-298.

15. Duncan, D. B. (1955) Multiple range and multiple $F$ test. Biometrics, 11: 1-42.

16. Sallam, S. M. A. (2005) Nutritive value assessment of the alternative feed resources by gas production and rumen fermentation In vitro. Research Journal of Agriculture and Biological Sciences, 1(2): 200-209.

17. Vitti, D. M. S. S., Nozella, E. F., Abdalla, A. L., Buenoa, I. C. S., Silva Filho, J. C., Costa, C., Buenod, M. S., Longo, C., Vieira, M. E. Q., Cabral Filho, S. L. S., Godoy, P. B. and Mueller-Harvey, I. (2005) The effect of drying and urea 
treatment on nutritional and anti-nutritional components of browses collected during wet and dry seasons. Animal Feed Science Technology. 122: 123-133.

18. Sallam, S. M. A., Bueno, I. C. S., Godoy, P. B., Nozella, E. F., Vitti, D. M. S. S. and Abdalla, A. L. (2008) Nutritive value assessment of the artichoke (Cynara scolymus) by-product as an alternative feed resource for ruminants. Tropic Subtropic Agroecosys. 8: 181- 189.

19. Medjekal, S., Arhab, R. and Bousseboua, H. (2011) Nutritive value assessment of some desert by-products by gas production and rumen fermentation in vitro. Livestock Research for Rural Development. 23 (3):217-222.

20. Wallace, R. J., Wallace, S. J. A., McKain, N., Nsereko, V. L., and Hartnell, G. F. (2001) Influence of supplementary fibrolytic enzymes on the fermentation of corn and grass silages by mixed ruminal microorganisms in vitro. Journal of Animal Science. 79: 1905-1916.

21. Tang, S. X., Tayo, G. O., Tan, Z. L., Sun, Z. H., Shen, L. X., Zhou, C. S., Xiao, W. J., Ren, G. P., Han, X. F. and Shen, S. B. (2008) Effects of yeast culture and fibrolytic enzyme supplementation on in vitro fermentation characteristics of low-quality cereal straws. Journal of Animal Science. 86: 1164-1172.

22. Weimer, P. J. (1996) Why don't ruminal bacteria digest cellulose faster? Journal of Dairy Science. 79: 1496-1502.

23. Jalilvand, G., Odongo, N. E., Lopez, S., Naserian, A., Valizadeh, F., Eftekhar Shahrodi, F., Kebreab, E. and France, J. (2008) Effects of different levels of an enzyme mixture on in vitro gas production parameters of contrasting forages. Animal Feed Science Technoogyl. 146: 289-301.

$* * * * * * * *$ 